\title{
TOTAL VIABLE COUNT OF TREATED WATER IN THE KANDY MUNICIPAL DISTRIBUTION SYSTEM
}

\author{
C. P. KODIKARA \\ Faculty of Veterinary Medicine and Animal Science, \\ University of Peradeniya, Peradeniya, Sri Lanka.
}

(Date of receipt : 06.05.86)

(Date of acceptance : 09.09.86)

\begin{abstract}
The general bacterial population of treated water in the Kandy distribution system was studied. The mean total viable counts at $35^{\circ} \mathrm{C}$ and $20^{\circ} \mathrm{C}$ were found to be $80 / \mathrm{ml}$ and $129 / \mathrm{ml}$ respectively. The mean total viable counts at $35^{\circ} \mathrm{C}$ and $20^{\circ} \mathrm{C}$ were not significantly different. The frequency of detection of coliforms was increased to levels up to a total viable count of $500 / \mathrm{ml}$ but decreased thereafter.
\end{abstract}

\section{Introduction}

Potable water of good bacteriological quality is generally associated with attainment of less than one total coliform $/ 100 \mathrm{ml}$ of water. Yet there are many other micro-organisms common to the flora of finished water whose numbers far exceed those of the coliform group. Some of these organisms may be a factor in creating health problems in very young and the debilitated persons in a community. 4,7 In addition high non-coliform population in finished water have been implicated in suppressing coliform growth in test media. $1,3,5$ Even though water treatment is adequate and $\mathrm{Cl}_{2}$ disinfection is provided, quality could deteriorate in the distribution system as a result of growth of organisms other than detectable coliforms.

Unless there is considerable collection of data within a country the total microbial count is difficult to use as a water quality standard. This study provides data with regard to the levels of non-fastidious heterotrophic bacteria in treated water in one of the main water distribution networks in Sri Lanka.

\section{Experimental}

Eighty-four samples of water from the Kandy water distribution system was examined for the total viable count and the total coliforms. The samples were collected from street standposts which are directly connected to the main and transported in accordance with the methods recommended by the 


\subsection{Total viable count}

One $\mathrm{ml}$ quantities of the sample and of the $10^{-1}$ dilution were added to petridishes and $5 \mathrm{ml}$ of glucose ex tract agar was poured over and mixed well. Duplicate plates for each dilution was used. After the plates were set, one set of plates were incubated at $35^{\circ} \mathrm{C}$ for 24 hours and the other set at $20^{\circ} \mathrm{C}$ for 48 hours. All colonies on selected plates (plates having colony numbers between 30 and 300) were counted after the incubation time.

\subsection{Total coliforms}

Most probable number technique using MacConkey broth was used in the estimation of total coliforms according to the WHO recommendations. ${ }^{10}$

\section{Results}

\subsection{Mean total viable count in the Kandy Water Distribution System}

The mean total viable counts, the standard deviation and the range of counts at the two incubation temperatures $35^{\circ} \mathrm{C}$ and $20^{\circ} \mathrm{C}$ are shown in Table 1 . The mean total viable counts at $35^{\circ} \mathrm{C}$ and $20^{\circ} \mathrm{C}$ are 80 and 129 respectively. A significant difference of viable counts was not observed by the " $t$ " test for paired observations.

Table 1. Mean total viable count and the Density by range in the Kandy water distribution system

\begin{tabular}{llll}
\hline & $\begin{array}{l}\text { No. of } \\
\text { Samples }\end{array}$ & $\begin{array}{l}\text { Mean and Stan- } \\
\text { dard Deviation }\end{array}$ & Range \\
\hline Total viable count at $35^{\circ} \mathrm{C}$ & 72 & $80 \pm 9$ & $1-1600 / \mathrm{ml}$ \\
Total viable count at $20^{\circ} \mathrm{C}$ & 73 & $129 \pm 11$ & $1-2200 / \mathrm{ml}$ \\
\hline
\end{tabular}

The percentage of samples in the different density ranges of the total viable count at $35^{\circ} \mathrm{C}$ and $20^{\circ} \mathrm{C}$ are shown in Tables 2 and 3.23 and $25 \%$ of the samples have total viable counts $\leqslant 10$ at $35^{\circ} \mathrm{C}$ and $20^{\circ} \mathrm{C}$ respectively. 
Table 2. Bacterial Plate Counts at $35^{\circ} \mathrm{C}$ Versus Coliform detection in water in the Kandy water distribution system

Total plate count

Density range/ml
Pour plate method $35^{\circ} \mathrm{C}$

No. of samples
Total coliforms

Occurrence Percentage

\begin{tabular}{rrrrrr}
\hline $1-10$ & 23 & 27.4 & 3 & 13 \\
$11-30$ & 12 & 14.3 & 1 & 8.3 \\
$31-100$ & 11 & 13.1 & 4 & 36.3 \\
$101-300$ & 11 & 13.1 & 5 & 45.4 \\
$301-500$ & 9 & 10.7 & 5 & 55.5 \\
$501-1000$ & 2 & 2.4 & 1 & 50 \\
& $>1000$ & 4 & 4.8 & 2 & 50 \\
Covered with & 12 & 14.2 & 10 & 83.3 \\
proteus
\end{tabular}

Table 3. Bacterial Plate Count at $20^{\circ} \mathrm{C}$ Versus Coliform detection in water in the Kandy water distribution system

Total plate count

Density range/ml
Pour plate method $20^{\circ} \mathrm{C}$

No. of samples
Percentage
Total coliforms

Occurrence Percentage

\begin{tabular}{rrrrrc}
\hline $1-10$ & 25 & 29.7 & 4 & 16 \\
$11-30$ & 4 & 4.8 & 0 & 0 \\
$31-100$ & 11 & 13.1 & 4 & 36.3 \\
$101-300$ & 12 & 14.3 & 8 & 66.6 \\
$301-500$ & 13 & 15.5 & 8 & 61.5 \\
$501-1000$ & 2 & 2.4 & 0 & 0 \\
& $>1000$ & 6 & 7.1 & 1 & 16.6 \\
Covered with & 11 & 13.1 & 6 & 54.5 \\
proteus & & & & \\
\end{tabular}




\subsection{Total viable count versus coliform detection}

The data presented in Tables 2 and 3 show the relationship between the total viable count and the detection of coliforms at the two temperatures $35^{\circ} \mathrm{C}$ and $25^{\circ} \mathrm{C}$. At $35^{\circ} \mathrm{C}$, the frequency of detecting coliforms does not show a significant increase after a total viable count of $500 / \mathrm{ml}$ (Table 2) and at $20^{\circ} \mathrm{C}$ the frequency of detecting coliforms increases upto a total viable count of $500 / \mathrm{ml}$ and decreases thereafter (Table 3).

\subsection{Percentage of samples of water below a total viable count of $500 / \mathrm{ml}$}

Of the samples of the Kandy distribution system 77 to $78 \%$ were below $500 / \mathrm{ml}$ at $20^{\circ} \mathrm{C}$ and $35^{\circ} \mathrm{C}$ respectively. In $13-14 \%$ of the total samples analysed it was unable to estimate an accurate count due to the plates being covered with proteus.

\section{Discussion}

The total viable count for drinking water as described in standard methods of American Public Health Association 1975, is the plating of small quantities (usually $1.0 \mathrm{ml}$ or $0.1 \mathrm{ml}$ ) of a properly collected water sample in a nutrient agar medium and incubating aerobically for a fixed period at a prescribed temperature $\left(35^{\circ} \mathrm{C}\right.$ for 24 hours in $20^{\circ} \mathrm{C}$ for 48 hours).

Although no constant relationship appears to exist between standard plate count and the number of potentially pathogenic invaders that might be present, it is logical to assume that change occurences are proportionally greater as the general bacterial population increases. In addition high non coliform populations in finished water have been implicated in suppressing coliform growth in test media. $1,3,5$ Therefore water having a high noncoliform population would indicate a negative coliform test giving the consumer a false sense of security. The initial level of suppression of coliforms has been shown to be a general bacterial population exceeding $1000 / \mathrm{ml}^{8}$. Therefore an establishment of a standard plate count limit of $500 / \mathrm{ml}$ in the distribution water has been considered as a useful measure. ${ }^{6}$

The results of the present study shows that the mean total viable count of Kandy distribution water is below $500 / \mathrm{ml}$ and therefore the adverse influence of excessive bacterial population interfering on routine monitoring procedures of the Kandy water distribution system could be considered very low. The present study too shows that the frequency of detection of coliforms increasing as the standard plate count increased to levels upto $500 / \mathrm{ml}$ but decreasing thereafter (Table 3 ). 
The total viable count could be considered as a quality control of water treatment processes and the efficacy of sanitation measures used on distribution lines. Fischer 5 indicates that a total viable count below $500 / \mathrm{ml}$ could be maintained in the distribution lines by maintaining a residual $\mathrm{Cl}_{2}$ level of approximately $0.3 \mathrm{mg} / 1$ throughout the distribution lines. Of the samples of the Kandy distribution water 77 to $78 \%$ showed counts below $500 / \mathrm{ml}$ at $20^{\circ} \mathrm{C}$ and $35^{\circ} \mathrm{C}$ respectively, indicating that the deterioration of water quality in the distribution system is very low.

Water used in food, beverage cosmetic and drug industries should be of a higher standard with regard to the total viable count because these organisms create taste, odor and spoilage problems in the finished products. ${ }^{2}$ It has been suggested that the water used in food processing should have a plate count of less than 50 bacteria/ml. ${ }^{2}$ With regard to the water in the Kandy distribution system supplemental treatment procedures are required if the water is used for food, beverage, cosmetic or drug industries to maintain good keeping properties of the products.

The importance of using two temperatures of incubation namely $20^{\circ} \mathrm{C}$ and $35^{\circ} \mathrm{C}$ in determining the total viable count is that $20^{\circ} \mathrm{C}$ covers the growth requirements of most natural soil and water bacteria and $35^{\circ} \mathrm{C}$ the organisms of animal human reservoir. In the present study the total viable counts at $20^{\circ} \mathrm{C}$ and $35^{\circ} \mathrm{C}$ were not significantly different. Theoretically, an increased count at $35^{\circ} \mathrm{C}$ is more critical from a hygienic point of view than an increased count at $20^{\circ} \mathrm{C}$.

\section{Acknowledgements}

The author gratefully acknowledges the financial assistance given by the Natural Resources, Energy and Science Authority of Sri Lanka.

References 1. AHMED, Z., POSHNI, I.A. \& SIDDIQUI, M. (1967). Pakistan J. Sci. Indust.
Res., $7: 103$. 2. BORGSTROM, S. (1968). Principles of Food Science, 11 : Food Microbiology and
Biochemistry. MacMillan Ltd., London.

3. BORING, I.J.R., MARTIN, W.T. \& ELLIOTT, L.M. (1971). Epidemiol., , $93: 49$.

Am. J.

4. FIERER, J., TAYLOR, P.M. \& GEZON, H.M. (1967). New England Journal
Medicine, $276: 991$. 
5. FISCHER, G. (1950). Zeit. Immun. U. Exp. Thero. $107: 16$.

6. GELDREICH, E., NASH, H.D., REASONER, D.J. \& TAYLOR, R.H. (1972). Journal of American water works association, 596-602.

7. LOWBURY, E.J.T., THORN, B.T., LILLY, H.A., BABE, J.R. \& WHITTALL, K. (1970). J. Microbiol., 3 : 39.

8. MCCABE, L.J., SYMONS, J.M., LEE, R.D. \& ROBECK, G.G. (1970). Journal of American water works association, $62: 11: 670$.

9. Standard Methods for the Examination of water and waste water, 14th edition, 1975. American Public Health Association.

10. WHO International Standards for drinking water 1971. 